\title{
Aplikasi Mobile Untuk Memantau Body Mass Index Dengan Metodologi Scrum
}

\author{
Esther Irawati Setiawan ${ }^{1,2 *}$, Hans Keven Budi Prakoso1, Tjwanda Putera Gunawan ${ }^{1}$, \\ Endang Setyati ${ }^{1,2}$, Joan Santoso ${ }^{1,2}$ \\ ${ }^{1}$ Program Studi Teknik Informatika, Institut Sains dan Teknologi Terpadu Surabaya, Jawa Timur \\ ${ }^{2}$ Program Studi Teknologi Informasi, Institut Sains dan Teknologi Terpadu Surabaya, Jawa Timur \\ Email: ${ }^{1,2 *}$ esther@stts.edu
}

(Naskah masuk: 01 Okt 2021, direvisi: 01 Nov 2021, 15 Nov 2021, diterima: 18 Nov 2021)

\begin{abstract}
Abstrak
Pandemi berkepanjangan menyebabkan adanya kecenderungan manusia untuk kurang bergerak dan berolahraga, sehingga terjadi peningkatan berat badan yang menyebabkan penurunan kualitas kesehatan. Di samping itu, teknologi smartphone dewasa ini semakin berkembang pesat dan telah menjadi kebutuhan sehari-hari. Oleh karena itu, teknologi smartphone sebaiknya dimanfaatkan sebaik mungkin, sehingga dapat digunakan dalam berbagai aspek kehidupan, seperti penghitungan Body Mass Index (BMI), yang diharapkan dapat mengontrol tingkat tumbuhnya obesitas pada masyarakat terutama di masa pandemi ini. Pengembangan aplikasi ini mencakup penggunaan kamera dalam penghitungan BMI. Jika pada umumnya penghitungan BMI dilakukan dengan menggunakan tinggi dan berat badan, aplikasi ini dapat menggunakan gambar dari kamera smartphone sebagai sumber datanya. Melalui pembuatan aplikasi penghitungan BMI ini, dapat disimpulkan bahwa metodologi Scrum sangat membantu dalam proses pencatatan perkembangan kerja task-task pembuatan aplikasi saat mengerjakan setiap sprint mulai sprint pertama hingga empat. Penghitungan BMI dengan menggunakan hasil gambar dari kamera memiliki tingkat akurasi sebesar $70 \%$.
\end{abstract}

Kata Kunci: BMI, Smartphone, Sprint, Scrum, Product Backlog.

\section{Development of a Mobile Application to Monitor Body Mass Index Using the Scrum Methodology}

\begin{abstract}
The prolonged pandemic causes a tendency for humans to be less active and exercise so that there is an increase in body weight which causes a decrease in health quality. In addition, today's smartphone technology is growing rapidly, and has become a daily necessity. Therefore, smartphone technology should be utilized as well as possible, so that it can be used in various aspects of life, such as calculating the Body Mass Index (BMI), which is expected to control the growth rate of obesity in the community, especially during this pandemic. The development of this application includes the use of cameras in calculating BMI. If BMI is generally calculated using height and weight, this application can use images from smartphone cameras as a data source. Through the creation of this BMI calculation application, it can be concluded that the Scrum methodology is very helpful in the process of recording the work progress of application creation tasks when working on each sprint from the first to fourth sprints. BMI calculation using the image from the camera has an accuracy rate of $70 \%$.
\end{abstract}

Keywords: Body Mass Index, Smartphone Application, Sprint Methodology, Scrum Methodology. 


\section{PENDAHULUAN}

Di masa pandemi saat ini, banyak pekerja yang harus bekerja dari rumah sehingga akhirnya kurang bergerak dan menyebabkan peningkatan berat tubuh hingga terkena obesitas [1]. Untuk mencegah hal ini, selain mengawasi berat badan, perlu adanya pengawasan terhadap Body Mass Index (BMI) untuk menjaga kualitas kesehatan seseorang. BMI adalah tolak ukur untuk mengukur persentase lemak tubuh manusia berdasarkan tinggi dan berat badan seseorang. Dengan menggunakan BMI, seseorang dapat mengetahui, apakah badan yang ia miliki sudah termasuk kategori ideal, atau belum, atau mungkin telah melewati kategori ideal tersebut [2]. BMI juga dapat digunakan untuk memantau apakah gizi yang diperoleh tubuh sudah memadai [3].

Pada pengerjaan penelitian ini, metode penghitungan BMI akan diterapkan dengan menggunakan 2 metode, yaitu dengan menggunakan penghitungan secara manual dan penghitungan yang dilakukan dengan menggunakan kamera smartphone. Kamera smartphone dipilih dalam pengerjaan penelitian ini karena pada saat ini smartphone sudah dimiliki oleh banyak orang dan telah menjadi salah satu kebutuhan sehari-hari masyarakat. Karena dimiliki oleh banyak orang, hal itu memudahkan penggunaan aplikasi yang akan dibuat.

Dengan menggunakan penghitungan BMI yang menjadi tolak ukur kondisi badan, user dapat mengecek kondisi badan dari hari ke hari. Untuk membantu user, pada pengerjaan penelitian ini akan ditambahkan sistem pemantauan penghitungan BMI, yang membandingkan hasil penghitungan dari hari ke hari.

Adapun perhitungan yang dilakukan oleh BMI tidak selalu tepat, karena BMI hanya menghitung ideal tidaknya badan seseorang berdasarkan tinggi dan berat badan. Perhitungan dapat dikatakan tidak tepat apabila seseorang melakukan pembentukan badan, di mana orang tersebut memiliki berat badan dan BMI yang tinggi, namun memiliki nilai massa otot yang tinggi, serta persentase lemak yang rendah. Selain itu, pengerjaan penelitian ini akan dilakukan pada smartphone yang memiliki sistem operasi Android. Hal ini dilakukan karena sistem operasi Android bersifat open source, sehingga dapat digunakan oleh seluruh orang.

Berbagai aplikasi kesehatan berbasis smartphone dikembangkan untuk merekomendasikan kesehatan pengguna [2]. Aplikasi [4] dirancang untuk memberikan saran latihan olahraga berdasarkan BMI, Basal Metabolic Rate (BMR), dan energi yang digunakan dalam setiap aktivitas atau olahraga. Aplikasi ini juga telah dirancang untuk menyajikan saran latihan khusus untuk pasien dengan masalah kesehatan. Selain itu, aplikasi telah dirancang untuk menyimpan informasi dalam database dan memiliki kemampuan untuk menghasilkan laporan kepada pengguna. Aplikasi perhitungan BMI juga dikembangkan untuk mendeteksi kekurangan gizi pada anak [5] [6]. Perhitungan BMI juga dapat dilakukan pada IoT [7].

Aplikasi kalkulator BMI telah dikembangkan untuk berbagai negara, salah satunya untuk memberikan saran makanan Malaysia [8]. Peneliti merancang dan mengembangkan aplikasi Android BMI Calc dengan tujuan menghitung BMI sambil menambahkan modul saran makan. Saran untuk sarapan, makan siang, dan makan malam didasarkan pada jumlah kalori yang dibutuhkan pengguna dan juga mempertimbangkan beberapa hidangan favorit Malaysia.

Penelitian ini membantu user untuk menghitung Body Mass Index dengan menggunakan kamera smartphone dan membantu user untuk memantau tingkat kebugaran badan user. Aplikasi juga memungkinkan user untuk melakukan penghitungan BMI di mana saja. Setelah user melakukan penghitungan BMI, sistem akan mengkategorikan kondisi tubuh user. Melalui fitur ini, user dapat mengetahui, apakah badan yang dimilikinya pada saat ini sudah mencapai kategori badan yang ideal, ataukah memerlukan perubahan bentuk badan, sehingga dapat menjadi ideal.

Setelah menyimpan histori BMI dari pengguna, aplikasi akan memberikan saran, hal apakah yang sebaiknya dilakukan oleh user. Melalui fitur ini juga, aplikasi akan menampilkan resiko-resiko yang sewaktu-waktu dapat terjadi pada user. Sebagai contoh, aplikasi menganalisis bahwa user memiliki kondisi badan obesitas tingkat 2. Pada tahap ini, aplikasi memperkirakan bahwa user memiliki resiko terkena penyakit jantung. Untuk menghindari hal ini, maka aplikasi menyarankan user untuk melakukan aktivitas berupa olahraga.

Akan tetapi, karena nilai BMI dan kondisi tubuh yang sangat tidak ideal, maka user memiliki kemungkinan cedera pada saat melakukan aktivitas olahraga tersebut. Oleh karena itu, user hanya dapat melakukan aktivitas olahraga tertentu, seperti berenang. Aplikasi akan menyarankan user untuk melakukan olahraga renang, yang memiliki potensi membakar banyak kalori dan memiliki resiko cedera yang lebih kecil apabila dibandingkan dengan olahraga lainnya. Sepengetahuan penulis, fitur saran dan pemantauan BMI beserta resiko kesehatan yang mungkin muncul adalah yang pertama dikembangkan di Indonesia.

Aplikasi juga memiliki sistem login. Sistem ini berguna untuk menyimpan data-data yang diinginkan oleh users tertentu, dan mungkin tidak berguna untuk user yang lain. Berikut adalah contoh beberapa data yang disimpan pada fitur login: email merupakan salah satu fitur yang terdapat hampir dalam setiap aplikasi yang memerlukan login. Melalui email, developer bisa mendapatkan data mengenai user. Selain itu, mereka juga bisa mengirimkan promosi/newsletter kepada user. Histori dari penghitungan BMI yang telah dilakukan dapat digunakan sebagai pembanding kondisi badan saat ini dengan kondisi badan saat pertama kali penghitungan dilakukan. Melalui histori, user dapat melihat apakah badan user telah menjadi lebih ideal, ataukah malah menjauh dari kondisi badan ideal.

Dengan melakukan login kepada beberapa situs media sosial, seperti Facebook dan Google, sistem dapat membaca seluruh kontak yang dimiliki oleh user. Oleh karena itu, sistem dapat menampilkan hasil BMI yang dimiliki oleh teman-teman user yang telah melakukan penghitungan BMI. Selain itu, user juga dapat membagikan hasil penghitungan yang telah dilakukan.

Artikel ini terdiri atas lima bagian. Bagian pertama membahas pendahuluan dan latar belakang. Bagian kedua menjelaskan mengenai tinjauan pustaka dan bagian ketiga 
mengenai metodologi penelitian. Bagian keempat mengupas mengenai hasil dan pembahasan, serta bagian terakhir membahas mengenai kesimpulan.

\section{TINJAUAN PUSTAKA}

Pada bagian ini akan dijelaskan mengenai berberapa teori dasar yang menjadi penunjang pada pembuatan aplikasi penghitungan BMI.

\section{A. Body Mass Index (BMI)}

BMI adalah perbandingan antara tinggi dan berat badan seseorang, yang digunakan untuk menghitung persentase lemak orang tersebut [9][10]. Dengan menggunakan BMI, user dapat mengetahui termasuk kategori manakah badan yang ia miliki. Dengan mengetahui kategori badan yang dimiliki, user dapat mengetahui resiko-resiko yang mungkin terjadi pada dirinya, apabila ia tetap memiliki berat badan yang tidak ideal. Adapun perhitungan dasar dari BMI ini adalah berat badan dibagi dengan tinggi.
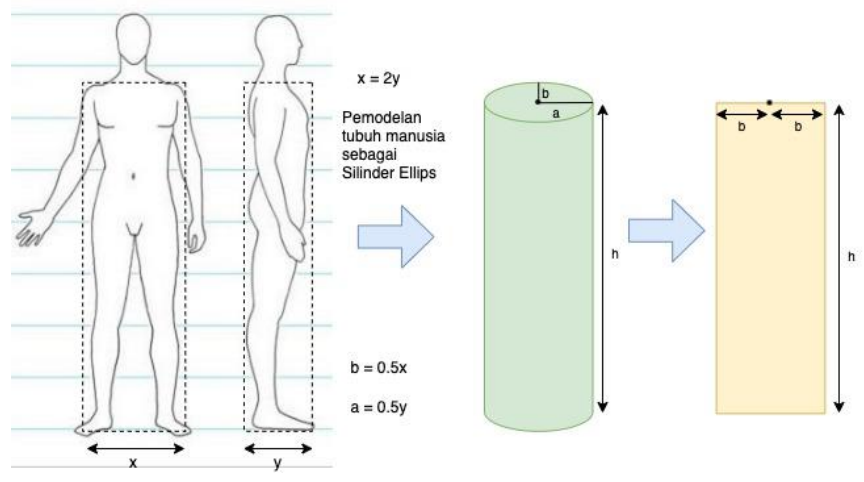

Gambar 1. BMI Menggunakan Gambar

Terdapat cara lain untuk menghitung BMI, yaitu dengan memperkirakan nilai BMI seseorang melalui gambar [11] yang ditampilkan pada Gambar 1. Hal ini bisa dilakukan, apabila manusia yang terdapat pada gambar dimodelkan menjadi bentuk silinder. Melalui bentuk silinder, kita dapat mengetahui perkiraan volume tubuh manusia yang terletak pada gambar. Karena $75 \%$ tubuh manusia terdiri dari air, dapat disimpulkan bahwa massa jenis manusia mendekati nilai massa jenis air, yaitu $1 \mathrm{gr} / \mathrm{cm}^{3}$. Karena volume dan massa jenis telah didapatkan dari gambar, maka berat badan dari manusia target penghitungan juga bisa didapatkan. Apabila berat manusia telah didapatkan, maka penghitungan akan dikembalikan kepada rumusan awal, yaitu nilai BMI ditentukan dari berat badan dibagi dengan tinggi. Walaupun metode yang digunakan untuk menghitung BMI melalui gambar memiliki tingkat akurasi yang baik, penghitungan BMI dengan menggunakan gambar memiliki tingkat akurasi sekitar $70 \%$.

$\mathrm{BMI}=$ Volume $/$ Tinggi $^{2}$

$\mathrm{BMI}=\left(\pi \mathrm{A}^{2}\right) / \mathrm{h}^{3}$
Rumus dasar dari penghitungan BMI adalah pembagian berat badan dengan tinggi kuadrat, dimana berat badan digantikan oleh volume, karena massa jenis tubuh manusia mendekati massa jenis air. Volume bisa dihasilkan dengan menggunakan rumusan luas dan tinggi dari gambar manusia.

Variation $=\frac{(A B S)(\text { Computed BMI-BMI })}{B M I} \times 100 \%$

Rumus 3 merupakan penghitungan variasi yang digunakan pada Tabel 1. Penghitungan variasi digunakan untuk mengecek apakah nilai BMI telah sesuai dengan penghitungan BMI konvensional atau tidak. Penghitungan dikatakan meleset apabila memiliki tingkat variasi di atas $10 \%$.

Tabel 1. Tabel Perbandingan BMI Konvensional dan Computed BMI Pada Paper

\begin{tabular}{rrr}
\hline $\begin{array}{c}\text { BMI Kovensional } \\
(\mathbf{K g} / \mathbf{m} \mathbf{2})\end{array}$ & $\begin{array}{c}\text { Computed BMI } \\
(\mathbf{K g} / \mathbf{m} \mathbf{2})\end{array}$ & $\begin{array}{c}\text { Variasi } \\
\mathbf{( \% )}\end{array}$ \\
\hline 20,89 & 17,26 & 17,38 \\
\hline 25,89 & 29,13 & 12,51 \\
\hline 24,66 & 23,37 & 5,23 \\
\hline 27,25 & 27,35 & 0,37 \\
\hline 19,89 & 18,48 & 7,09 \\
\hline 23,42 & 26,43 & 12,85 \\
\hline 19,71 & 20,47 & 3,86 \\
\hline 23,45 & 21,64 & 7,72 \\
\hline 18,17 & 16,24 & 10,62 \\
\hline 22,81 & 23,68 & 3,81 \\
\hline & &
\end{tabular}

Tabel 1 berisi tentang perbandingan Computed BMI dan penghitungan BMI dengan menggunakan cara konvensional. Perbandingan ini ditujukan untuk mengecek apakah rumusan penghitungan BMI yang terdapat paper telah sesuai dengan hasil penghitungan BMI konvensional. Pada Tabel 1 terdapat kolom variasi, dimana variasi ini berguna untuk mengecek apakah Computed BMI paper yang digunakan memiliki perbedaan nilai yang jauh dengan penghitungan BMI konvensional. Penghitungan dikatakan tidak tepat sasaran apabila memiliki tingkat variasi di atas $10 \%$. Dapat dilihat pada Tabel 1 , terdapat total 4 penghitungan yang memiliki tingkat variasi di atas $10 \%$. Penghitungan tersebut dianggap meleset, karena tidak memenuhi standar. Jumlah penghitungan tabel yang dianggap meleset adalah $40 \%$. Dapat disimpulkan bahwa penghitungan memiliki tingkat akurasi sebesar $60 \%$.

\section{B. OpenCV}

OpenCV atau open source computer vision library adalah library perangkat lunak yang ditujukan untuk pengembangan computer vision dan machine learning. Karena sifatnya yang merupakan open source, OpenCV dapat dengan mudah digunakan dan dimodifikasi oleh developer.

Library OpenCV sendiri terdiri lebih dari 2.500 algoritma. Algoritma-algoritma ini dapat digunakan untuk mendeteksi wajah, mengenali suatu objek, menentukan ada tidaknya manusia dalam sebuah video, melacak objek yang bergerak, 
dan lain-lain. Library ini banyak digunakan oleh perusahaan, grup peneliti, dan badan pemerintah.

Open $C V$ adalah salah satu library terbesar yang pernah ada, dapat digunakan untuk berbagai tujuan, baik untuk akademis maupun untuk komersial, dan mendukung berbagai macam bahasa pemrograman, seperti $\mathrm{C}++, \mathrm{C}$, Phyton dan Java. Selain itu, library ini mendukung berbagai platform pembuatan software, seperti Linux, Mac OS, iOS, Windows dan Android. OpenCV memiliki komunitas yang terdiri lebih dari 47.000 orang, dan jumlah download yang lebih dari 14 juta salinan.

Penggunaan library OpenCV ini ditujukan untuk membantu penelitian yang akan dibuat, terutama pada bagian pendeteksian tubuh manusia pada gambar yang didapat. Pada library Open $C V$, terdapat fitur people detect, yang bisa mendeteksi tubuh manusia.

\section{Scrum}

Scrum merupakan perkembangan dari metodologi Agile, dan merupakan salah satu metodologi yang paling sering digunakan dalam pengembangan aplikasi mobile. Metodologi Scrum menggunakan strategi fleksibel, dimana hasil yang dapat mulai terlihat pada awal fase pengerjaan. Dengan demikian proses eksekusi program dapat diubah sewaktuwaktu, sekalipun pada saat pengerjaan tugas tengah dilakukan. Penjelasan singkat untuk lima tahapan dalam Scrum adalah sebagai berikut:

- Sprint Planning: Tahapan ini merupakan tahapan paling awal, dimana tim akan melakukan perencanaan yang bertujuan untuk membahas hal yang perlu dilakukan pada sprint, memilih Product Backlog, serta mempersiapkan sebuah sprint.

- Sprint Daily Meeting: Merupakan tahapan meeting yang dilakukan setiap hari. Tujuan dari tahapan ini adalah untuk menentukan task manakah yang dikerjakan pada hari pengerjaan sprint.

- Daily Scrum: Merupakan tahapan meeting yang dilakukan setiap hari. Tujuan dari tahapan ini adalah untuk mengerjakan task yang telah ditentukan sebelumnya, untuk setiap harinya pada saat sprint.

- Sprint Review: Tahap ini dilakukan setelah sebuah sprint dijalankan. Tahap ini menunjukkan hasil demo yang telah dibuat pada sebuah sprint, kemudian melakukan review pada hasil demo yang telah dibuat. Setelah itu, tim akan membahas hal apa yang akan dilanjutkan setelahnya.

- Retrospective: tahap ini melakukan introspeksi diri terhadap sprint yang telah dilakukan sebelumnya. Setiap anggota pada tim Scrum akan mengidentifikasi proses yang harus dilakukan agar terdapat perkembangan pada tim Scrum.

Salah satu alasan utama untuk menggunakan metodologi Scrum dalam pengerjaan penelitian ini adalah karena Scrum memiliki basis metodologi Agile. Berikut adalah beberapa kelebihan dari metodologi Agile untuk pengembangan aplikasi Mobile [12].

- Fleksibel: proses eksekusi dari pengerjaan proyek dapat diubah sewaktu-waktu, sesuai dengan kebutuhan. Oleh karena itu, developer dapat meminimalisir adanya bug, dan membuat aplikasi menjadi lebih stabil. Selain itu, developer juga dapat menempatkan fitur-fitur baru dengan lebih mudah.

- Aplikasi berjalan dengan lebih cepat: salah satu ciri aplikasi mobile yang baik ialah proses eksekusi aplikasi yang cepat. Metodologi Agile mementingkan kecepatan proses aplikasi itu sendiri, sehingga sangat cocok digunakan pada aplikasi mobile.

- Lebih tahan lama: pada umumnya, sebuah aplikasi mobile memiliki umur sekitar 12 bulan. Umur dari aplikasi ini dapat diperpanjang dengan menggunakan metodologi Agile. Metodologi ini selalu menghasilkan solusi-solusi dari masalah yang ada, sehingga aplikasi dapat beradaptasi dan bertahan lebih lama.

\section{METODOLOGI PENELITIAN}

Pada bagian ini akan dijelaskan tentang metodologi yang digunakan dan cara kerja metodologi tersebut untuk aplikasi penghitungan BMI. Desain arsitektur aplikasi untuk user member ditampilkan pada Gambar 2.

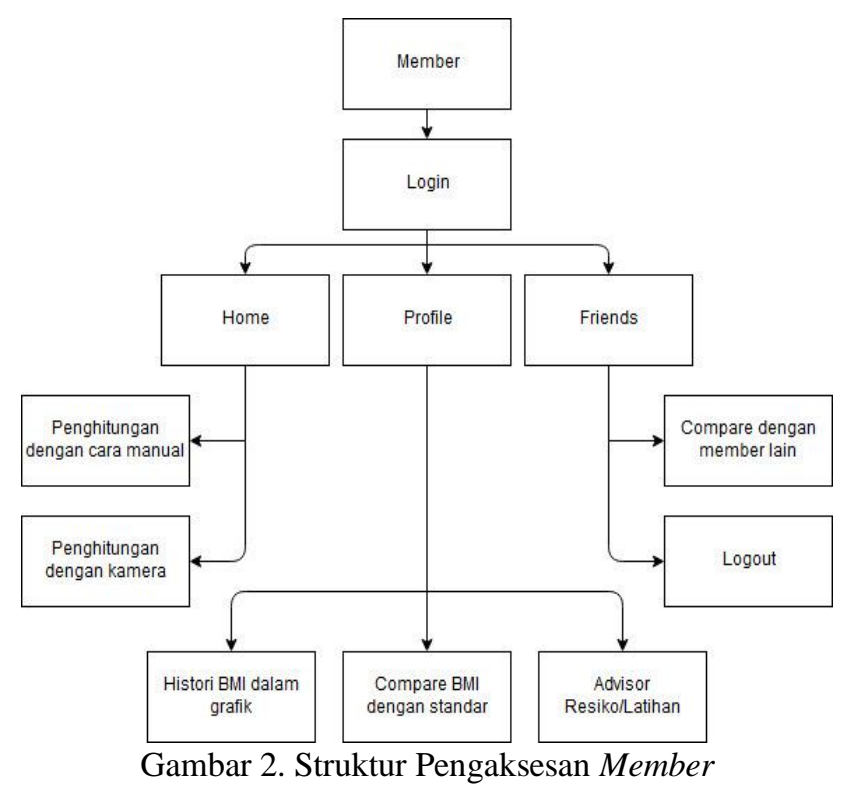

Metodologi pengembangan aplikasi menggunakan Scrum yang akan dijelaskan setiap tahapannya. Tahapan pertama adalah Sprint Planning yang berfokus pada Product Backlog. Product Backlog yang dihasilkan diperlukan untuk kepentingan aplikasi penghitungan BMI. Product Backlog yang merupakan kumpulan dari user story keinginan Product Owner.

Product Backlog untuk user guest dapat dilihat pada Tabel 2, yang merupakan daftar user story dari user guest dimana pada kolom pertama merupakan kolom identitas untuk diproses lebih lanjut sebagai penanda dari daftar keinginan seorang Guest yang ditandai dengan huruf G, diikuti dengan nomor urutan. Kolom kedua merupakan keinginan dari user itu sendiri, dan kolom ketiga berisi tujuan dari keinginan user. 
Tabel 2. User Story Guest

\begin{tabular}{|c|c|c|c|}
\hline ID & $\begin{array}{c}\text { Yang } \\
\text { Diinginkan }\end{array}$ & Tujuan (Goal) & $\begin{array}{l}\text { Kategori } \\
\text { Fitur }\end{array}$ \\
\hline G1 & $\begin{array}{l}\text { Saya ingin } \\
\text { dapat } \\
\text { menghitung } \\
\text { BMI dengan } \\
\text { cara normal }\end{array}$ & $\begin{array}{l}\text { Dapat } \\
\text { menghitung } \\
\text { BMI dengan } \\
\text { cara normal }\end{array}$ & $\begin{array}{l}\text { Penghitungan } \\
\text { BMI normal }\end{array}$ \\
\hline G2 & $\begin{array}{l}\text { Saya ingin } \\
\text { dapat } \\
\text { menghitung } \\
\text { BMI dengan } \\
\text { kamera }\end{array}$ & $\begin{array}{l}\text { Dapat } \\
\text { menghitung } \\
\text { BMI dengan } \\
\text { menggunakan } \\
\text { kamera }\end{array}$ & $\begin{array}{l}\text { Penghitungan } \\
\text { BMI dengan } \\
\text { kamera }\end{array}$ \\
\hline G3 & $\begin{array}{l}\text { Saya ingin } \\
\text { dapat melihat } \\
\text { resiko dari } \\
\text { penghitungan } \\
\text { BMI }\end{array}$ & $\begin{array}{l}\text { Dapat melihat } \\
\text { resiko penyakit } \\
\text { yang terjadi }\end{array}$ & $\begin{array}{l}\text { Advisor } \\
\text { resiko }\end{array}$ \\
\hline G4 & $\begin{array}{l}\text { Saya ingin } \\
\text { melihat jenis } \\
\text { latihan yang } \\
\text { disarankan }\end{array}$ & $\begin{array}{l}\text { Dapat melihat } \\
\text { latihan yang } \\
\text { disarankan }\end{array}$ & $\begin{array}{l}\text { Advisor } \\
\text { latihan }\end{array}$ \\
\hline G5 & $\begin{array}{l}\text { Saya ingin } \\
\text { melihat hasil } \\
\text { BMI yang lama }\end{array}$ & $\begin{array}{l}\text { Dapat melihat } \\
\text { perkembangan } \\
\text { BMI }\end{array}$ & Histori BMI \\
\hline
\end{tabular}

Tahapan selanjutnya adalah Sprint Daily Meeting. Pengembangan aplikasi ini melalui empat Sprint Daily Meeting. Semua Sprint Planning Meeting ini dipimpin oleh Product Master, dihadiri oleh team development yang terdiri dari desainer, programmer, dan tester. Sprint Planning Meeting ini dilakukan sebelum proses sprint keempat dimulai. Awal Sprint keempat membicarakan tentang detail task atau yang disebut sebagai subtask, dan dikerjakan oleh siapa serta tanggal perencanaan pengerjaannya tampak pada Tabel 3.

Tabel 3. Hasil Sprint Planning Meeting 4

\begin{tabular}{cc}
\hline & Sprint Planning Meeting 4 \\
\hline Tanggal & 9 Februari 2019 \\
\hline Milestone & 11 Februari 2019 - 25 Februari 2019 \\
\hline Peserta & Scrum Master dan Team Development \\
\hline $\begin{array}{c}\text { User } \\
\text { Story: }\end{array}$ & \\
\hline & G2 Penghitungan BMI dengan kamera \\
& {$[$ Han3] [11-2-2019] - [18-2-2019] } \\
\hline 1 & Input data dengan kamera \\
\hline 2 & Hitung nilai BMI \\
\hline 3 & Save data BMI \\
\hline 4 & Testing (verify) penghitungan BMI \\
\hline & A2.1 Master user \\
\hline & [Han3] [19-2-2019] - [25-2-2019] \\
\hline 1 & Load data user \\
\hline 2 & Load data BMI user \\
\hline & A2.1.1 Profile BMI user \\
\hline 1 & LHan2] [11-2-2019] - [18-2-2019] \\
\hline
\end{tabular}

\begin{tabular}{lc}
\hline 2 & Load profil BMI user \\
\hline 3 & Show profil user \\
\hline & A2.1.2 Profile user data \\
& {$[$ Han1] [25-2-2019] $-[25-2-2019]$} \\
\hline 1 & Load data diri user \\
\hline 2 & Show user data \\
\hline
\end{tabular}

Tahapan Daily Scrum merupakan tahapan meeting yang dilakukan setiap hari. Pengembangan aplikasi ini melalui empat Daily Scrum. Pada saat mengerjakan sprint pada tahap keempat, mulai dipantau setiap harinya, untuk melaporkan progress yang didapat pada setiap harinya oleh setiap anggota tim. Scrum Master melakukan Daily Meeting ini maksimum 15 menit dan dianggap sebagai stand up meeting, dan progress dari setiap anggota tim akan dicatat, sehingga anggota tim berhak untuk menilai hasil kerja seberapa besar progress yang didapat, atau bisa dilakukan komentar pada setiap task-nya.

Tahap Sprint Review dilakukan setelah sebuah sprint dijalankan. Terdapat empat Sprint Review Meeting. Sprint Review Meeting pertama ini dilakukan setelah sprint pertama selesai dilakukan. Adapun tipe Sprint Review Meeting pada sprint pertama ini juga diperlukan membuat tipe task baru seperti pada yang dilakukan saat Daily Meeting. Jika saat Sprint Review Meeting seluruh pekerjaan telah selesai dilakukan, maka status dari pekerjaan statusnya diubah menjadi close, dan tidak dilanjutkan pada Scrum berikutnya.

Pada Sprint Review Meeting pertama ditentukan algoritma untuk perhitungan BMI manual pada Algoritma 1.

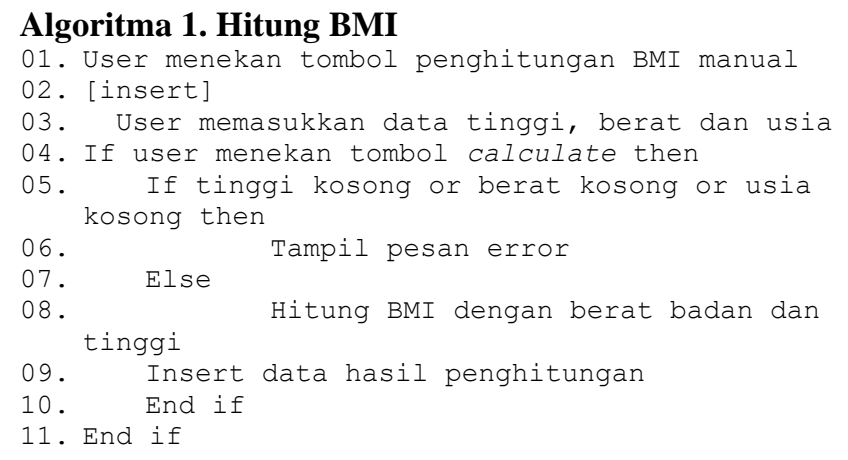

Sedangkan pada sprint meeting kedua ditentukan algoritma untuk Advisor resiko seperti pada Algoritma 2. Algoritma ini dimulai dari user menekan tombol profil, dimana kemudian aplikasi akan mengambil data berupa nilai BMI user, lalu membandingkan nilai BMI tersebut dengan tabel detail kategori, kemudian membandingkan lagi hasilnya dengan tabel kategori. Setelah mendapatkan kategori user, aplikasi akan mengambil data dari tabel resiko dan detail resiko, memperkirakan hasil yang didapat dari tabel tersebut, dan kemudian menampilkan hasilnya agar dapat dibaca oleh user aplikasi.

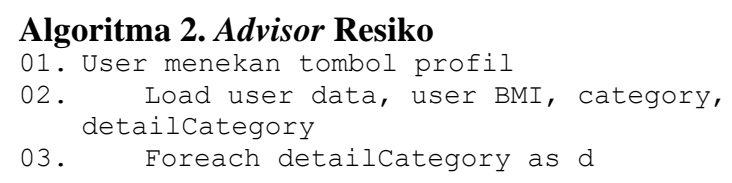




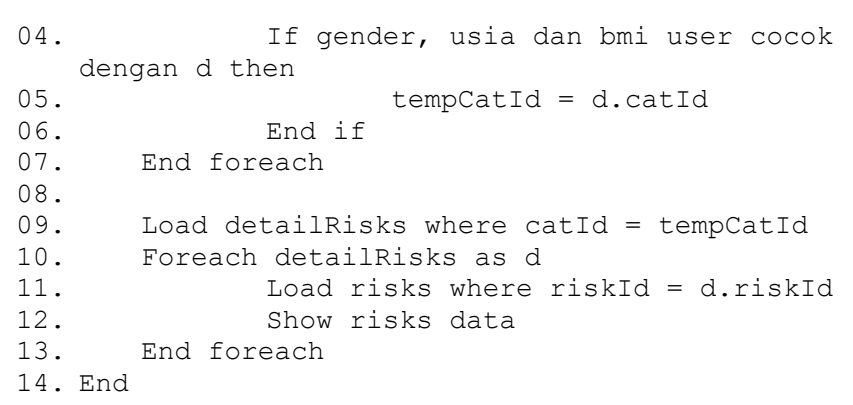

Selain itu juga dihasilkan Algoritma 3 untuk perhitungan BMI dengan kamera. Algoritma ini dimulai dari user menekan tombol penghitungan BMI kamera dan fasilitas pada algoritma ini berupa calculate, yang berguna untuk menghitung nilai BMI berdasarkan data yang telah dimasukkan. Karena gambar yang didapat dari kamera smartphone Android tidak memiliki fitur tinggi, berat badan dan usia dari user, maka pengisian data pada field tinggi, berat badan dan usia memiliki nilai kosong. Apabila data yang dimasukkan telah memenuhi kriteria penghitungan, maka aplikasi akan memproses gambar, dan kemudian memasukkan data hasil masukkan tersebut ke dalam database. Perhitungan BMI ini menggunakan bantuan library OpenCV.

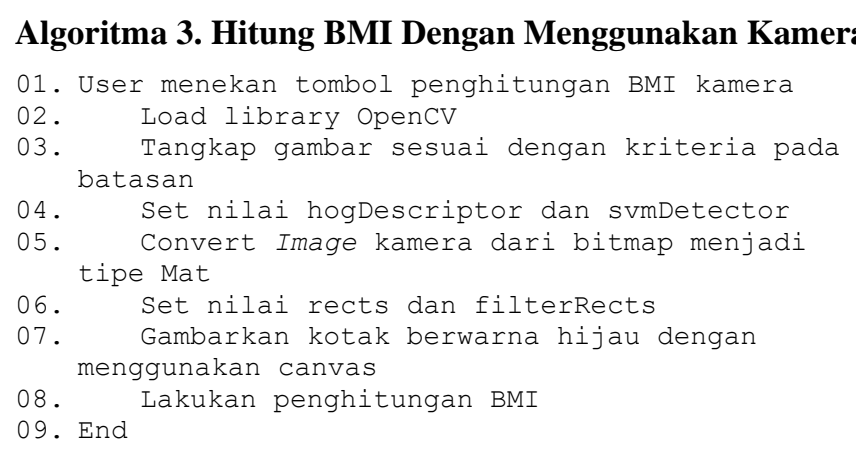

Tahap terakhir adalah Retrospective Meeting. Pada sprint retrospective meeting pertama ini digunakan untuk kepentingan kemajuan dalam tim ini, tetapi tidak terimbas pada faktor teknikal. Sifat meeting ini membahas hal-hal yang dapat memudahkan dalam kepentingan rapat, ataupun komunikasi yang lebih sederhana. Sprint retrospective meeting kedua digunakan untuk kepentingan kemajuan dalam team ini, tetapi tidak terimbas pada faktor teknikal. Sprint retrospective meeting ketiga sudah berjalan dengan benar, semua yang sudah berjalan dengan lancar dari sisi komunikasi serta rapat-rapat yang diperlukan untuk keefektifan dalam pengerjaan proyek ini. Pada akhirnya, sprint retrospective meeting keempat berjalan dengan benar, semua yang sudah berjalan dengan lancar dari sisi komunikasi serta rapat-rapat yang diperlukan untuk keefektifan dalam pengerjaan proyek ini.

\section{HASIL DAN PEMBAHASAN}

Pada bagian ini akan membahas tentang uji coba aplikasi. Uji coba yang dimaksud adalah uji coba dari fitur-fitur yang sudah dibuat di dalam aplikasi ini. Dengan adanya uji coba ini akan diketahui kekurangan dari aplikasi ini dan pasti kekurangan itu akan dikembangkan lebih lanjut agar para user semakin terbantu dalam penggunaan aplikasi penghitungan BMI ini. Tujuan dari uji coba ini adalah mengamati respons dari aplikasi ketika fitur dijalankan oleh user dan memastikan tidak ada fitur yang tidak dapat dijalankan.

Uji coba yang dilakukan Functional Testing, Usability Testing, dan Compatibility Testing. Uji fitur functional testing yang dilakukan ditampilkan pada Tabel 4.

Tabel 4. Tabel Uji Coba

\begin{tabular}{|c|c|c|}
\hline Percobaan & $\begin{array}{c}\text { Hasil yang } \\
\text { Diharapkan }\end{array}$ & Hasil \\
\hline $\begin{array}{l}\text { Penghitungan } \\
\text { BMI Manual }\end{array}$ & $\begin{array}{l}\text { Menghitung BMI } \\
\text { dengan meng-input-kan } \\
\text { data secara manual }\end{array}$ & $\begin{array}{l}\text { Berjalan } \\
\text { dengan baik }\end{array}$ \\
\hline $\begin{array}{l}\text { Penghitungan } \\
\text { BMI Kamera }\end{array}$ & $\begin{array}{l}\text { Menghitung BMI } \\
\text { dengan input-an } \\
\text { gambar kamera }\end{array}$ & $\begin{array}{l}\text { Berjalan } \\
\text { dengan baik }\end{array}$ \\
\hline Histori BMI & $\begin{array}{l}\text { Daftar histori } \\
\text { penghitungan BMI } \\
\text { yang telah dilakukan }\end{array}$ & $\begin{array}{l}\text { Berjalan } \\
\text { dengan baik }\end{array}$ \\
\hline $\begin{array}{l}\text { Histori dengan } \\
\text { Grafik }\end{array}$ & $\begin{array}{l}\text { Histori dengan bentuk } \\
\text { grafik }\end{array}$ & $\begin{array}{l}\text { Berjalan } \\
\text { dengan baik }\end{array}$ \\
\hline Advisor Resiko & $\begin{array}{l}\text { Daftar resiko yang } \\
\text { mengancam user } \\
\text { dengan nilai BMI } \\
\text { terntentu }\end{array}$ & $\begin{array}{l}\text { Berjalan } \\
\text { dengan baik }\end{array}$ \\
\hline Advisor Latihan & $\begin{array}{l}\text { Daftar latihan yang } \\
\text { disarankan untuk BMI } \\
\text { tertentu }\end{array}$ & $\begin{array}{l}\text { Berjalan } \\
\text { dengan baik }\end{array}$ \\
\hline $\begin{array}{l}\text { Perbandingan } \\
\text { BMI }\end{array}$ & $\begin{array}{l}\text { Membandingkan BMI } \\
\text { dengan user lainnya }\end{array}$ & $\begin{array}{l}\text { Berjalan } \\
\text { dengan baik }\end{array}$ \\
\hline $\begin{array}{l}\text { Login dengan } \\
\text { Google }\end{array}$ & $\begin{array}{l}\text { Login dengan email } \\
\text { Google }\end{array}$ & $\begin{array}{l}\text { Berjalan } \\
\text { dengan baik }\end{array}$ \\
\hline
\end{tabular}

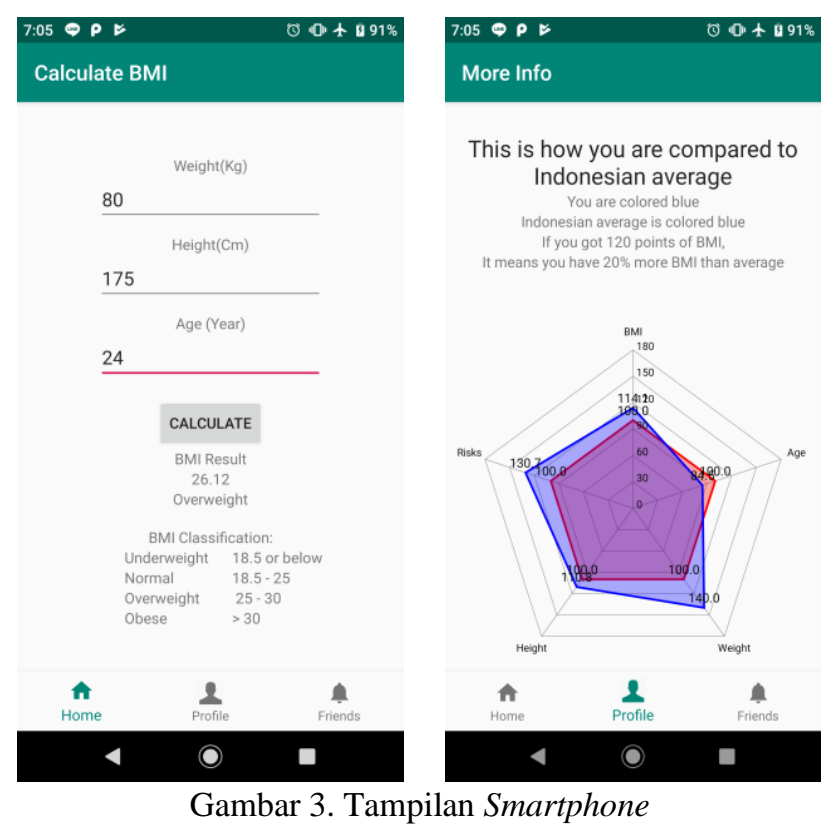

Gambar 3. Tampilan Smartphone 
Uji coba compatibility testing juga dilakukan di smartphone yang berbeda. Smartphone yang digunakan untuk uji coba adalah Xiaomi Redmi 5A dengan sistem operasi Android 7.1.2 (Nougat) dan Xiaomi Mi A2 dengan sistem operasi Android 8.1 (Oreo). Tampilan dalam smartphone juga di buat seefisien mungkin dalam menampilkan aplikasi penghitungan[13][14][15]. Aplikasi berjalan dengan baik, dan tidak ada kendala, tampilan juga tetap rapi dan tidak ada masalah. Setiap fitur juga berjalan dengan baik. Contoh tampilan ada pada Gambar 3 dan Gambar 4.

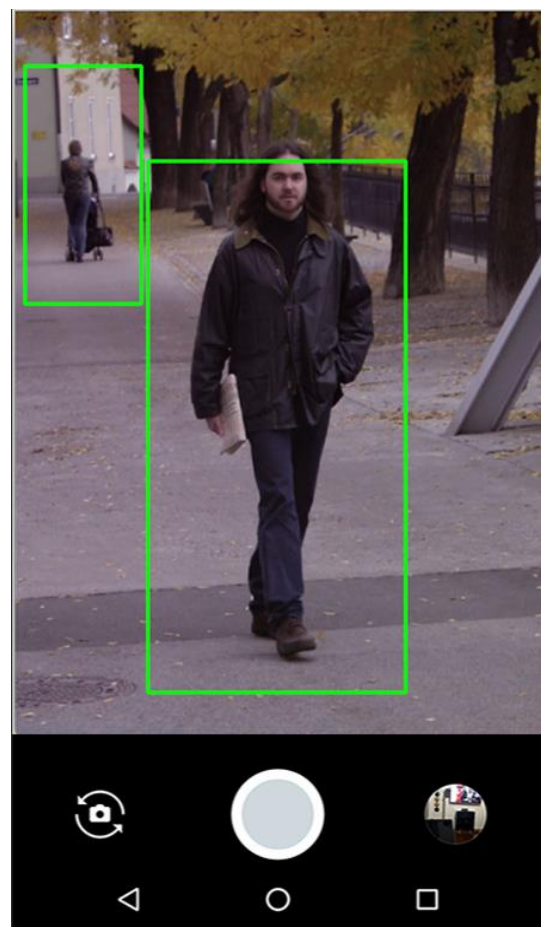

Gambar 4. Tampilan Perhitungan BMI dari Kamera

Tampilan pada smartphone yang berbeda tidak terlalu mempunyai efek, bahkan hasil yang didapatkan dari tampilan terbilang sama. Hal ini karena pada saat pengembangan aplikasi digunakan constraintLayout, yang berguna untuk membuat tampilan yang dinamis, dan dapat terlihat rapi pada setiap device, salah satunya seperti terlihat pada Gambar 4.

Tabel 5. Tabel Perbandingan Computed BMI Pada Paper Dengan Computed BMI Aplikasi

\begin{tabular}{ccc}
\hline $\begin{array}{c}\text { Computed BMI } \\
\text { Paper } \\
(\mathbf{K g} / \mathbf{m} 2)\end{array}$ & $\begin{array}{c}\text { Computed BMI } \\
\text { Aplikasi } \\
(\mathbf{K g} / \mathbf{m} 2)\end{array}$ & $\begin{array}{c}\text { Variasi } \\
(\boldsymbol{\%})\end{array}$ \\
\hline 17,26 & 17,225 & 0,2 \\
\hline 29,13 & 29,064 & 0,23 \\
\hline 23,37 & 23,313 & 0,24 \\
\hline 27,35 & 27,318 & 0,37 \\
\hline 18,48 & 18,43 & 0,12 \\
\hline 26,43 & 26,408 & 0,08 \\
\hline 20,47 & 20,42 & 0,24 \\
\hline 21,64 & 21,618 & 0,1 \\
\hline
\end{tabular}

\begin{tabular}{ccc}
\hline 16,24 & 16,197 & 0,26 \\
\hline 23,68 & 23,657 & 0,1 \\
\hline 20,93 & 20,892 & 0,18 \\
\hline 24,85 & 24,815 & 0,14 \\
\hline 19,50 & 19,483 & 0,09 \\
\hline 24,39 & 24,342 & 0,2 \\
\hline 24,95 & 24,89 & 0,24 \\
\hline
\end{tabular}

Tabel 5 berisi tentang perbandingan Computed BMI yang terdapat paper dan Computed BMI yang dilakukan pada aplikasi, dengan menggunakan variabel area dan tinggi yang sama. Pada tabel ini terdapat kolom variasi, dimana variasi ini berguna untuk mengecek apakah Computed BMI Aplikasi yang telah dibuat memiliki perbedaan nilai yang jauh dengan yang terdapat pada paper. Dapat dilihat pada tabel, perbedaan yang dimiliki oleh paper dan aplikasi sangatlah sedikit, berkisar antara $0,2 \%$. Berdasarkan hasil ini, dapat disimpulkan bahwa fungsi penghitungan BMI dengan masukan area dan tinggi manusia telah sesuai dengan paper, dan dapat digunakan pada penghitungan BMI.

Tabel 6. Tabel Penghitungan BMI Dengan Menggunakan Gambar Pada Aplikasi

\begin{tabular}{cccc}
\hline $\begin{array}{c}\text { Area } \\
(\text { Pixel })\end{array}$ & $\begin{array}{c}\text { Height } \\
(\text { Pixel })\end{array}$ & Image BMI & $\begin{array}{c}\text { Computed } \\
\text { BMI } \\
(\mathbf{k g} / \mathbf{m} 2)\end{array}$ \\
\hline 59187 & 568 & 7,51 & 17,225 \\
\hline 70618 & 584 & 9,84 & 29,064 \\
\hline 71973 & 616 & 8,71 & 23,313 \\
\hline 76624 & 624 & 9,49 & 27,318 \\
\hline 69222 & 624 & 7,75 & 18,43 \\
\hline 83313 & 664 & 9,31 & 26,408 \\
\hline 90877 & 736 & 8,14 & 20,42 \\
\hline 83313 & 688 & 8,37 & 21,618 \\
\hline 80565 & 704 & 7,31 & 16,197 \\
\hline 77954 & 648 & 8,77 & 23,657 \\
\hline 63275 & 576 & 8,23 & 20,892 \\
\hline 64798 & 568 & 9 & 24,815 \\
\hline 75600 & 656 & 7,95 & 19,483 \\
\hline 74227 & 624 & 8,91 & 24,342 \\
\hline 59448 & 536 & 9,02 & 24,89 \\
\hline
\end{tabular}

Tabel 6 adalah contoh penghitungan yang dilakukan aplikasi terhadap gambar. Terdapat 4 kolom pada tabel, yaitu area sebagai area luasan badan yang terdeteksi oleh aplikasi, height sebagai tinggi dari manusia yang terdeteksi aplikasi, penghitungan Image BMI dimana data ini didapat dari penghitungan area dan tinggi target penghitungan, dan Computed BMI yang merupakan hasil akhir dari BMI penghitungan.

Uji coba juga dilakukan dengan Usability Testing dan membagi kuesioner. Kuesioner ini ditujukan untuk orang yang memiliki usia antara 17-50. Dengan adanya kuesioner ini dapat dilihat kekurangan dan kelebihan dari aplikasi ini. Berikut hasil dari pengisian kuesioner yang sudah dilakukan oleh beberapa user. 


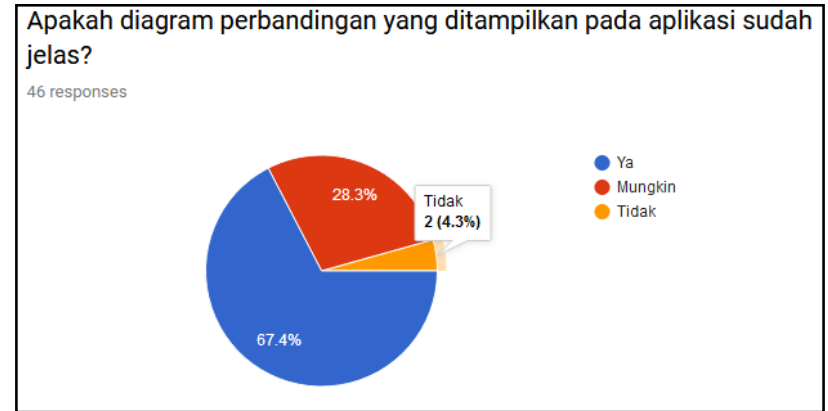

Gambar 5. Pertanyaan Pertama

Gambar 5 merupakan diagram dari pertanyaan "Apakah diagram perbandingan yang ditampilkan pada aplikasi sudah jelas?". Gambar 5 adalah representasi dari jawaban yang dikumpulkan melalui kuesioner yang sudah disebar. Terdapat total 46 orang yang mengisi kuesioner ini. Total 31 orang menjawab sudah jelas dengan persentase $67,4 \%, 13$ orang responden masih bingung akan jawabannya dengan persentase $28,3 \%, 2$ orang responden menjawab tidak dengan persentase $4,3 \%$.

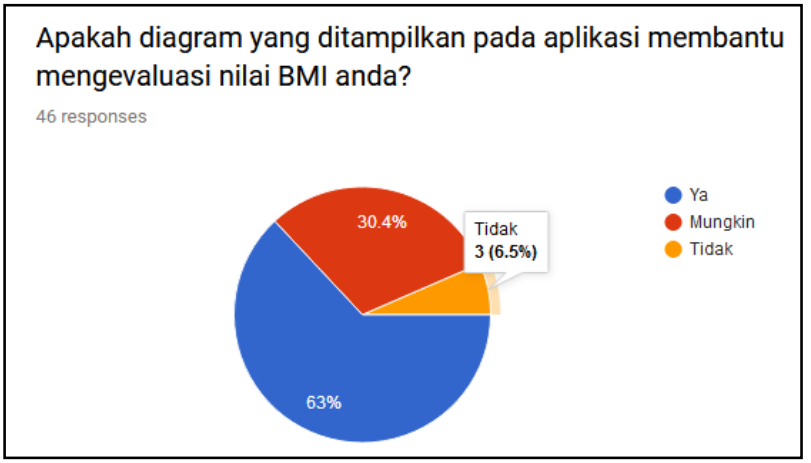

Gambar 6. Pertanyaan Kedua

Gambar 6 merupakan diagram dari pertanyaan "Apakah diagram yang ditampilkan pada aplikasi membantu mengevaluasi nilai BMI anda?". Gambar 6 adalah representasi dari jawaban yang dikumpulkan melalui kuesioner yang sudah disebar. Terdapat total 46 orang yang mengisi kuesioner ini. Total 29 orang menjawab ya dengan persentase $63 \%, 14$ orang responden masih bingung akan jawabannya dengan persentase $30,4 \%, 3$ orang responden menjawab tidak dengan persentase $6,5 \%$.

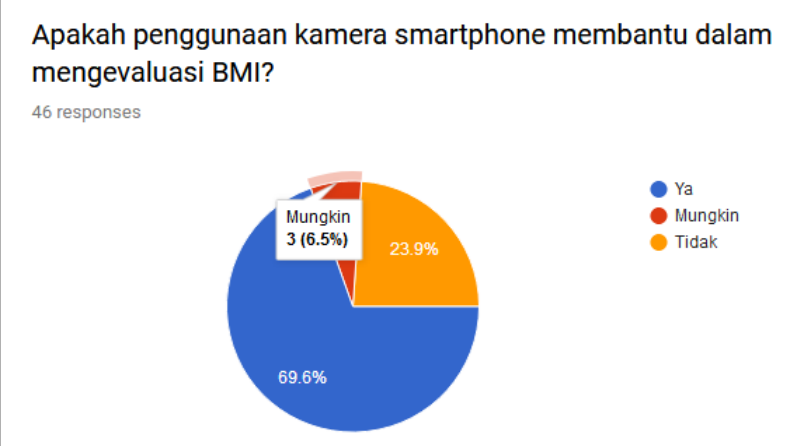

Gambar 7. Pertanyaan Ketiga
Gambar 7 merupakan diagram dari pertanyaan "Apakah penggunaan kamera smartphone membantu dalam mengevaluasi BMI?". Gambar 7 adalah representasi dari jawaban yang dikumpulkan melalui kuesioner yang sudah disebar. Terdapat total 46 orang yang mengisi kuesioner ini. Total 32 orang menjawab sudah jelas dengan persentase $69,6 \%, 3$ orang responden masih bingung akan jawabannya dengan persentase $6,5 \%, 11$ orang responden menjawab tidak dengan persentase $23,9 \%$.

Apakah diagram histori membantu anda dalam mengevaluasi BMI? 46 responses
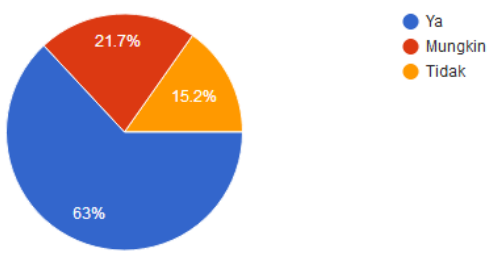

Gambar 8. Pertanyaan Keempat

Gambar 8 merupakan diagram dari pertanyaan "Apakah diagram histori membantu anda dalam mengevaluasi BMI?”. Gambar 8 adalah representasi dari jawaban yang dikumpulkan melalui kuesioner yang sudah disebar. Terdapat total 46 orang yang mengisi kuesioner ini. Total 29 orang menjawab sudah jelas dengan persentase $63 \%, 10$ orang responden masih bingung akan jawabannya dengan persentase $21,7 \%, 7$ orang responden menjawab tidak dengan persentase $15,2 \%$.

Apakah anda merasa terbantu dalam melakukan penghitungan BMI selama menggunakan aplikasi?

46 responses

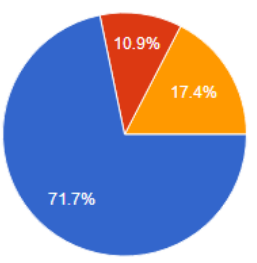

Ya

Mingkn

Tidak

Gambar 9. Pertanyaan Kelima

Gambar 9 merupakan diagram dari pertanyaan "Apakah anda merasa terbantu dalam melakukan penghitungan BMI selama menggunakan aplikasi?”. Gambar 9 adalah representasi dari jawaban yang dikumpulkan melalui kuesioner yang sudah disebar. Terdapat total 46 orang yang mengisi kuesioner ini. Total 33 orang menjawab sudah jelas dengan persentase $71,7 \%, 5$ orang responden masih bingung akan jawabannya dengan persentase $10,9 \% .8$ orang responden menjawab tidak dengan persentase $17,4 \%$. 


\section{PENUTUP}

Pada bagian ini akan dibahas tentang kesimpulan dan saran yang diambil selama pembuatan penelitian ini. Kesimpulan dari penelitian ini yang pertama adalah Penghitungan BMI dengan menggunakan hasil gambar dari kamera memiliki tingkat akurasi sebesar 70\%. Hasil ini didapatkan dengan jarak foto 2-3 meter, lebar foto lebih dari 250 pixel, dan tinggi foto lebih dari 500 pixel. Selain itu, library OpenCV, khususnya pada bagian Image Processing, sangat berguna dalam proses penghitungan BMI dengan menggunakan gambar kamera, yang terdapat pada pengerjaan penelitian. Selain itu, sesuai dengan tujuan pengembangan penelitian ini, hasil usability testing menunjukkan bahwa pengguna terbantu dengan fitur diagram history dan Advisor Latihan. Kesimpulan terakhir adalah metodologi Scrum sangat membantu dalam proses pencatatan progress kerja task-task pembuatan aplikasi saat mengerjakan setiap sprint mulai sprint pertama hingga empat.

Saran pengembangan aplikasi ini adalah dapat ditambahkan fitur rekomendasi menu sesuai BMI dari pengguna.

\section{REFERENSI}

[1] Lange, S.J., Kompaniyets, L., Freedman, D.S., Kraus, E.M., Porter, R., et.al. (2021). Longitudinal Trends in Body Mass Index Before and During the COVID-19 Pandemic Among Persons Aged 2-19 Years-United States, 2018-2020. Morbidity and Mortality Weekly Report, Vol. 70(37), pp. 1278-1283.

[2] Abana, E.C., Llamelo, C., Daña, T.B., Cafugauan, R.I., Maypada, N.A. \& Maramag, A.C. (2020). BMI Assessment Machine With Recommended Ideal Weight. International Journal of Advanced Trends in Computer Science and Engineering, Vol. 9(3).

[3] Hambali, S. \& Suwandar, E. (2019). Body Mass Index Artistic Gymnastics Athlete in West Java. JUARA: Jurnal Olahraga, Vol. 4(2), pp. 84-89.

[4] Rao, V.S. \& Krishna, T.M. (2014). A Design of Mobile Health for Android Applications. American Journal of Engineering Research (AJER), Vol. 3(6), pp. 20-29.
[5] Rathod, V.C., Jori, A., Kashid, A. \& Chavan, V. (2021). The Review Paper on Body Mass Index (BMI) Calculator of Child Malnutrition System. Journal of Emerging Technologies and Innovative Research (JETIR), Vol. 8(6), pp. 836-839.

[6] Suryanto, A., Paramita, O. Pribadi, F.S. (2017). The Development of Android-Based Children's Nutritional Status Monitoring System, AIP Conference Proceedings, Vol. 1818(1).

[7] Ismail, B.U., Ali, S.F.A. \& Ayaz, A.A. (2012). Microcontroller Based Automated Body Mass Index (BMI) Calculator with LCD Display.

[8] Ali, I.M. \& Samsudin, N. (2016). The Design and Development of BMI Calc Android Application. IOP Conference Series: Materials Science and Engineering, Vol. 160(1).

[9] Bartholomew, B.W. (2013). A Comparison of Body Adiposity Index and Body Mass Index to Body Fat Percentage in Young Adult Non-athletes and Athletes. University of Florida.

[10] Ferrera, L.A. (2006). Focus on Body Mass Index and Health Research. Nova Publishers.

[11] Madariaga, N.E.Q. \& Noel, B.L. (2016). Application of Artificial Neural Network and Background Subtraction for Determining Body Mass Index (BMI) in Android Devices Using Bluetooth. International Journal of Engineering and Technology, Vol. 8(5), pp. 366-370.

[12] Sutherland, J. \& Sutherland, J.J. (2014). Scrum: the Art of Doing Twice the Work in Half the Time. Currency.

[13] Rouson, D., Xia, J. \& Xu, X. (2011). Scientific Software Design: the Object-oriented Way. Cambridge University Press.

[14] Nudelman, G. (2013). Android Design Patterns: Interaction Design Solutions for Developers. John Wiley I\& Sons.

[15] Alencar, P. (2012). Handbook of Research on Mobile Software Engineering: Design, Implementation, and Emergent Applications, Vol. 1. IGI Global. 